\title{
Assessing the Perception and Practice of Teachers in Teaching the Integrated Reading and Writing Skills: Grade 11 in Focus
}

\author{
Firenesh Abebe Menamo (MSc.) ${ }^{1} \quad$ Birhanu Hankamo Kintamo (MSc.) ${ }^{2}$ \\ 1.Department of English, Ansho Preparatory and Secondary School, Ethiopia \\ 2.Department of economics, Wolaita Sodo University, Ethiopia
}

\begin{abstract}
The main objective of this study was to investigate the integration of writing and reading skills in grade eleven English textbook. In order to gathers data from the subjects of the study, observation, interview and writing task evaluation were used. Results from the observation indicated that the integration of writing and reading skills is being practiced to some extents in grade eleven through the basic procedures of the language skills integration approach are not followed. The result from the interview calculated with grade eleven English teachers showed that theoretically all of the English language teachers have good understandings on the improvement in integrating writing and reading skills in class practice. Result from the textbook evaluation related that most writing and reading tasks are integrated. Regarding the factors that negatively affect the implementation of skills integration especially writing and reading skills in Grade eleven, the following were identified as outstanding impediments: students' background, lack of students' interests, the size of textbook, limited classes' time, and shortage of classrooms and teaching materials in the schools.
\end{abstract}

Keywords: Integration, Skills-integration, classroom practice, reading comprehension, writing comprehension. DOI: $10.7176 /$ JLLL/59-05

Publication date: August $31^{\text {st }} 2019$

\section{INTRODUCTION}

\subsection{Background of the Study}

Throughout history, there have been many approaches for the teaching of English. All of them have been used during a period of time and then have been "replaced" by new approaches that proposed new ways for helping foreign students to reach a better proficiency of English as second or foreign language. For a few years there have been many opinions reinforcing the idea of language as a whole and proposing that the integration of the English language skills is the key for creating a classroom environment as authentic as possible in order to teach English in a way close to a real communicative situation. They propose that the English language should be taught in a way that mixes reading and listening comprehension with oral and written expression (Widdowson, 1978).

The philosophy of integrated-skill interaction is based on the concept that in natural, day to day experience, oral and written language are not kept separate and isolated from one another. Instead, they often occur together, integrated in specific communication events (Peregoy and Bole, 2001, as cited in Chen, 2007). This approach is consistent with the principles of the communicative language teaching as both of them emphasize meaningful and authentic language use and link oral and written language development.

Communicative language teaching (CLT) is an approach to language teaching that emphasizes authenticity, interaction, student-centered learning, task-based activities, and communication for real-world, and meaning full purposes. Furthermore, it is an eclectic blend of the contributions of previous methods into the best of what a teacher can provide in authentic uses of the second language in the classroom (Brown, 2007).Moreover, CLT is being practiced today, foreign language teaching methodologist such as Harmer (1991), McDonough(2003), Selinker and Tomlin(1986), Grabe and Stoller(2001), as cited in Alemayehu (2008), respectively remark the overall benefits of the integrated skills approach. Widdowson (1978) is also one of the first linguists to call for integrating the four language skill in instruction to raise learners' proficiency levels and enable advanced language learning. Researcher also emphasizes that virtually all language uses takes place in the form of discourse and in specific social contexts.

According to Freman (2000), the principles of CLT emphasize the importance of using a language to communicate and learn it. Therefore, to use the language in real life communication outside and inside the classroom, students need to have better communicative competence in the language. For example, Krashen (1993) found out that reading exposure or reading for genuine interest with a focus on meaning provides language learners with written comprehensible input similar to oral comprehensible input. He argues that reading contribute to second language acquisition in the same way as listening does, and proposes that reading contributes to competence in writing just a listening help develop the ability to speak. The teacher should provide students with appropriate language input to develop their own leaning by responding verbally as they read, write and learn in English because it is the integrated use or oral and written language proficiency (Peregioy and Boyele, 2001, as cited in Chen, 2007). 
Integrating language skills enables students to development of communicative competence in English. In addition to this, integrated language skill interaction allows' the teachers to track student' progress in four skills at the same time. If English language teachers teach language skill like vocabulary and grammar these aspects can accelerate the students' language learning Krashen (1993). Therefore, the contextualized integration of reading and writing skill is one part of skill integration that encourages student engagement with reading and writing process in the ways that go further than sentence level. In line with above scholar views, the study attempts to assess the perception and practice of teachers in teaching integrated Reading and Writing skills.

\subsection{Statement of the problem}

The successful instruction in both reading and writing are best learned when they are not taught in isolation from each other (Harmer, 2007). The relationship between reading and writing is a bit like that of chicken and egg. Which came first is not as important as the fact that without one the other cannot exist; moreover, reading and writing are regarded as the products of skills acquisition (Newman, 1985).

Promoting reading comprehension and focusing on writing are considered highly important in contextual in content and language integrated learner methodology (Wolff, 2005, as cited in Loranc-Paszyl, 2009). From this idea, the integrated reading and writing activities brings benefits to the learner with respect to both content learning and language learning processes.

The prominent factor that motivated the present researcher to focus on this study is that integrated reading and writing skills is highly recommended to support learner learning of English language. Since they are so closely linked, mutually reinforce each other and, therefore, promote learning when they are integrated in the class room activities. Their integration allows for multiple approaches to tasks, covering all learning styles (Cobine, 1995).students become better readers, writers and thinkers when they learn reading and writing together (Carson,1993 and Spack, 1998).Besides, the other reason that motivated the researcher to embark on this topic is the researcher's experience. As the researcher is currently an English teacher of Grade 11, he has good opportunities to observe different grade 11 English language teaching teachers teaching learning process (real class room teaching).they have little chance to practice the integrated reading and writing skills in integrated way; both skills are usually taught as separate. Therefore, they felt that the two skills complement each other and are best taught and learned together. For this reason, the researcher wants to assess the perception and practice of grade eleven English language teaching teachers in teaching integrated reading and writing skills. In addition to this, the related research work have also underlined that the absence of integration of the four skills of the English language, concerning the methodologies used to teach them which affect the student performance during lessons (Harmer, 2007).

However, to some extent there is related local study which was carried out on integrated skills teaching practice so far. For example, Alemaehu N. (2008) study focuses on by assessing the practical implementation and obstacles of integrated skills teaching. The study revealed that the teachers had high theoretical orientations and understanding of integrated-skills teaching principles. On the other hand, it was found that the teachers lacked practical skills of implementing integrated-skills teaching in classrooms. What makes the current study differs from previous studies was more attention was given to the perception and practice of teachers in teaching integrated reading and writing skills class of high school teachers; specifically grade11 English language teaching teachers. Thus, the main objective of the study was assessing the Perception and Practice of Teachers in Teaching of Integrated Reading and Writing Skills: Grade 11 in Focus.

\subsection{Objective of the study}

The main objective of this study was assessing the Perception and Practice of Teachers in Teaching the Integrated Reading and Writing Skills. Specifically, to point out the extent to which the teachers practice in integrating reading and writing skills, the perception of teachers in integrating reading and writing skills and Identify factors that affect Grade 11 English language teachers' to integration of writing and reading skills

\section{RESEARCH METHODOLOGY}

\subsection{Research design}

There is only one government preparatory school in Ansho town. The researcher took Ansho Secondary and preparatory as her research site. The researcher believed that, it is easy to conduct the research in study area without several challenges. In connection to this, Williams (2008) suggests that when the research site is convenient for the researcher, it has its own effect in determining the quality of the final findings. Thus, the school was selected based on convenient sampling.

\subsection{Participant of the study}

The subjects of the study were Ansho secondary and preparatory school English language teachers who are assigned to teach English language in grade eleven. In this school there are four English language teachers who 
taught Grade eleven students. Researcher took all four grade eleven English language teaching teachers as respondent.

\subsection{Sampling techniques}

The data for the study were gathered using two instruments of data collection. Classroom observation and unstructured interview.

\subsection{Tools of data collection}

For the success in collecting the data for the study, the researcher adopted different steps. At the beginning, to collect data from the respondents and get their acceptance, the researcher first discussed the purpose of the study with selected school 'Ansho secondary and preparatory' principals and grade eleven English language teachers. After getting permission, the data collection process begin by using the developed data gathering tools step by step.

The continuous classroom observation was conducted by using checklist and field note to capture the actual classroom practice taking in teaching the integrated reading and writing skills. The researcher observed the teaching of integrated reading and writing class eight times. Each observation session lasted for 42 minute. The researcher recorded practices of teachers in teaching integrating reading and writing skills on her notebooks, and put a tick mark $(\sqrt{ })$ under the column 'yes' or 'No' based on the practice that took place in teaching integrated reading and writing skills. The field note consisted of a written record of what happened in the classroom.

The researcher acted as non-participant observer in the classroom, setting at the back of the classroom taking note on the verbal and behavioral exchanges between the teachers and the students as well as among the students themselves. This is because the rationale of classroom observation was, to understand on how the teachers practice skills integration particularly reading and writing skills integration and classroom interactions.

Before conducting the interview, the researcher also arranged the times with grade 11 English language teachers. At the beginning, the researcher told the objectives of the interviews for all teachers who selected for interviews. Then, the researcher conducted the interview with teachers at different times and responses were recorded.

\subsection{Data analysis methods}

For this study, the data gathered through classroom observation and unstructured interview. Accordingly, the data from the classroom observation checklist was analyzed using following steps. Firstly, the researcher checked out whether the data gathered through the checklist and field notes in each integrated reading and writing lesson were ticked and recorded appropriately. Secondly, for each statement in the checklist, the frequencies that the researcher put a tick mark $(\sqrt{ })$ in column 'Yes' or 'No' were counted and changed in to percentage. And also the researcher checked how much reading and writing were integrated one to another in language teaching.

The researcher had discussed the data from field note in summery of the classroom observation inanition to the checklist result. In discussing the interview data for this study, the first stepwas transcribing the responses from the tape-recorder onto blank sheets of paper and then discussed transcribed data in word in summery form. After data had properly transcribed, the next step was coding the responses. Then, each theme from the coded data interpreted and discussed. Lastly, the result was discussed and then implications were drawn according to the views of the majority of the participants.

\section{DATA ANALYSIS AND INTRTPRTATION}

\subsection{An Overview of the Subjects of the Study}

Before discussing the data collected for this study, giving an account of explanation about the research subject is of paramount significance. As mentioned in chapter three, data for this study were gathered from the observation session conducted in four Grade eleven English Language Teachers' in teaching of integrated reading and writing classes at Duna Woreda Ansho Secondary and Preparatory school. In conducting unstructured interview a total of 4 respondents were participated in the study

\subsection{Result of the study}

3.2.1. Checklist Result on Teachers' Practice in teaching of Integrated Reading and Writing skills.

The tables below shows statement of the practices of teachersin teaching integrated reading and writing skills lesson with "Yes", and "No" column indicating the frequency of data relating to the eight days lesson observations at school. 
Table 3.1: checklist Results on Teachers' Practices in Teaching of

Integrated Reading and Writing skills

\begin{tabular}{|c|c|c|c|c|c|}
\hline \multirow[t]{2}{*}{ No. } & \multirow[t]{2}{*}{ Practice in integrated Reading and Writing lesson } & & \multicolumn{3}{|c|}{$\begin{array}{l}\text { Availability on the } \\
\text { lesson }\end{array}$} \\
\hline & & & Yes & No & Total \\
\hline \multirow[t]{2}{*}{1} & \multirow{2}{*}{$\begin{array}{l}\text { The teacher lets the students knows the objectives of the daily } \\
\text { lesson(he/she tells the students that they will practice writing skills by } \\
\text { integrating it with reading skills) }\end{array}$} & $\mathrm{F}$ & 1 & 7 & 8 \\
\hline & & $\%$ & 12.5 & 87.5 & 100 \\
\hline \multirow[t]{2}{*}{2} & \multirow{2}{*}{$\begin{array}{l}\text { The teacher encourages students read the given passage and he asks them } \\
\text { to move on to the writing exercise in the textbook. }\end{array}$} & $\mathrm{F}$ & 4 & 4 & 8 \\
\hline & & $\%$ & 50 & 50 & 100 \\
\hline \multirow[t]{2}{*}{3} & \multirow{2}{*}{$\begin{array}{l}\text { The teacher orders students to follow clear procedure/ planning, drafting } \\
\text { and revising / which help them to learn the writing skills in integrating } \\
\text { with reading skills }\end{array}$} & $\mathrm{F}$ & 2 & 6 & 8 \\
\hline & & $\%$ & 25 & 75 & 100 \\
\hline \multirow[t]{2}{*}{4.} & \multirow{2}{*}{$\begin{array}{l}\text { The teacher teaches language elements (vocabulary, grammar, } \\
\text { punctuation, spelling and capitalization) in writing by integrating it with } \\
\text { by reading text }\end{array}$} & $\mathrm{F}$ & 1 & 7 & 8 \\
\hline & & & 12.5 & 87.5 & 100 \\
\hline \multirow[t]{2}{*}{5} & \multirow{2}{*}{$\begin{array}{l}\text { The teacher gives students group work activities that help them write } \\
\text { various texts by integrating with reading text. }\end{array}$} & $\mathrm{F}$ & 2 & 6 & 8 \\
\hline & & $\%$ & 25 & 75 & 100 \\
\hline \multirow[t]{2}{*}{6} & \multirow{2}{*}{$\begin{array}{l}\text { The teacher asks students to select some of the ideas discussed in the } \\
\text { passage and write some paragraphs to persuade, explain, and inform by } \\
\text { their own words. }\end{array}$} & $\mathrm{F}$ & 3 & 5 & 8 \\
\hline & & $\%$ & 37.5 & 62.5 & 100 \\
\hline \multirow[t]{2}{*}{7} & \multirow{2}{*}{$\begin{array}{l}\text { The teacher present information in the passage in the form of picture, } \\
\text { tables, charts, outlines, graphs and asks students write in paragraph form. }\end{array}$} & $\mathrm{F}$ & 0 & 8 & 8 \\
\hline & & $\%$ & 0 & 100 & 100 \\
\hline \multirow[t]{2}{*}{8} & \multirow{2}{*}{$\begin{array}{l}\text { The teacher prepares a list of guidelines for writing a summery and he asks } \\
\text { students to write a paragraph summarizing the reading passage }\end{array}$} & $\mathrm{F}$ & 1 & 7 & 8 \\
\hline & & $\%$ & 12.5 & 87.5 & 100 \\
\hline \multirow[t]{2}{*}{9} & \multirow{2}{*}{$\begin{array}{l}\text { The teacher asks students to select some of the ideas discussed in the } \\
\text { passage and write some paragraphs to persuade, explain, and inform by } \\
\text { their own words. }\end{array}$} & $\mathrm{F}$ & 2 & 6 & 8 \\
\hline & & $\%$ & 25 & 75 & 100 \\
\hline \multirow[t]{2}{*}{10} & \multirow{2}{*}{$\begin{array}{l}\text { The teacher encourages students to use vocabulary and grammar in the } \\
\text { reading text in their writing. }\end{array}$} & $\mathrm{F}$ & 1 & 7 & 8 \\
\hline & & $\%$ & 12.5 & 8.5 & 100 \\
\hline
\end{tabular}

Source: own survey result, 2018

As indicated in table 3.1 above, on statement one, out of eight class observations, it was seen that the teachers did not tell the purposes of the lessons in $7(87.5 \%)$ of the observed lesson. On the other hand one of the teachers as heard telling the students the relevance of learning writing with reading in $1(12.5 \%)$ of the observations. From this finding it might be possible to infer that writing and reading lessons are not frequently handled. In statement 2, out of the eight reading and writing lesson observation made, the teachers were seen during this in half $4(50 \%)$ of the observations. From this finding, it might be seen that the teachers particularly to integrate reading and writing skills. Out of eight observation made in statement 3 , teachers were seen not applying this activity in the $6(75 \%)$, while was seen in $2(25 \%)$ of the observation made. This probability further implies that the students hardly apply planning, drafting and revision that reflect integrating reading and writing skills.

The data from the eight reading and writing lesson observations on statement 4 depicts that teachers were not seen teaching language element in reading and writing texts in $7(87.5 \%)$ of the observations. But they consider language element $1(12.5 \%)$ reading and writing skills integration. From this, it might be concluded that the other language elements are not given attention in teaching reading and writing skills integration; this implies that teachers mostly focused on the topics of the daily lesson in teaching the reading and writing skills rather than helping students use the language elements in their reading and writing lesson.

However, in majority $6(75 \%)$ of the observation made in statement 5 the teachers were not seen making students practice these activities, but seen in $2((25 \%)$. From this, one can infer that group work writing activities that help the students to write various texts by integrating with reading texts, as one type of activity, is not fully practiced in most of reading and writing classes.

As stated in statement 6, the data from the observation section depicts that the teachers were not seen practicing this technique in 5(62.5\%) observations made. But were seen in 3(37.5\%) of the observation. From this, it might be concluded that the practices of teaching reading and writing skill integration is not fully employed in the reading and writing classes. What was seen from statement7, during observation section none of the teachers presents information in the passages in the form of tables, charts, outlines, graphs and students write in paragraph form. From this, it might be concluded that using activities in statement 7 not given attention to present the information in the given reading texts in the process integration of reading and writing skills. As a 
result, students might not use the reading texts easily to integrate it with writing skill.

Based on table 4.1 however, the data from the observation session depicted that the teachers were not seen practicing statement 8 techniques in $7(87.5 \%)$, but in $1(12.5 \%)$ of the observation session, From this finding, it is possible to say that teacher do not give attention on preparing guidelines for teaching summary in addition to the points motivated in student's textbook. In the same that table above, observation made on statement 9showed that the teachers are not seen using most of writing class time for active involvement of student in integration of reading and writing in $6(75 \%)$ of the observation session. However, it was seen during the eight observations in which the teachers were seen involving students in writing activities through integrating with reading text in $2(25 \%)$ of the observation session. This implies that the teachers cover most of the writing class time for the presentation of the writing lesson which is mostly dominated by the teachers talk.

Reading texts are taken as a source of vocabulary and grammar for students in practicing writing activities. Lastly in statement 10 , however, $1(12.5 \%)$ of observation session seen that teacher making their students use vocabulary and grammars to integration of reading and writing but not seen in $7(87.5 \%)$. As a result, the students may not have awareness on how to use the vocabulary and grammar in the reading texts for practicing writing.

In general, as the checklist results indicate, in some of reading and writing lesson, the teachers show effort to help students to practice reading and writing activities by integrating them, therefore, it can be concluded that to some extents Grade Eleven English language teachers integrate reading and writing skills. However, the integration of reading and writing skills is not fully employed in some of the reading and writing lesson.

\subsubsection{The Significance of Integrating Reading and Writing Skills}

In responding to the first item of the interview, almost all of the four respondents suggested that integrated skills approach teaching particularly reading and writing is appropriate to enhance students reading and writing skills integration. In their further explanation they stated that when students integrate reading and writing skills, they can have opportunity to develop both skills. There is a belief that the more students read, the more they think and write better. In their detailed explanation, Resp2 and Resp3 strongly underline that when students read, even they learn the way the texts is developed by analyzing the given reading texts. For further understanding, let us see what Resp4 said:

In my opinion, teaching reading and writing skills Integra tingly is better than the separating one. If you simply pick up some topics and give students to write a paragraph about it, without any doubt students will be confused. Because they write based on what they know. However, if I teach them Integra tingly, at least they will have background knowledge on what they want to write on. Again, they may get some language inputs that help them I their writings from the reading texts.

Therefore, the responses from all respondents implied that teachers have awareness to the importance of integrating reading and writing skills in the process of teaching.

\subsubsection{Strategies used by Teachers to Integrate Reading and Writing skills}

When the respondents were asked the strategies they use in integrating reading and writing skills, Resp1 said that he teaches reading lessons by integrating with writing texts since most of the skills are integrated in the textbook. In his further explanations, when he taught the readinglesson by integrating it with writing texts, first he gives the reading text for students to read individually. Then, students read the text and write down what they understand from the reading texts. Finally, he asks them write similar texts in their own words.

Accordingly, Resp2 and Resp3 mentioned that they first make students to read and pick out the main points from the given reading texts. Second, they ask them to relate the ideas of the reading text with their real-lives. At the end, they ordered them to write similar texts on the situations in their villages using the ideas they got from the reading texts. In more detailed fashion, Resp4 highly stressed his opinion as follows:

As an English teacher to integrate the reading and writing activities in the process of teaching reading and writing skills, I use the following procedures. First, I make students to read the given reading texts. Second, I tell them to write the main points from what they read. Third, I give a clue for them to identify the organization of the texts (what types of writings are presented in the given reading texts). Finally, I ask them to write the summary of the reading text. I also give them some of the related topics and ask them to write on these topics in their own words. After that I help them where necessary, students write their idea on the given topics. For example when I teach letter writing I uses the above steps. Thus before coming to the writing activity, they see the parts of the sample letters the way it is written, the language used in it (formal or informal) and the organization of ideas in the given letter. Then they come to write their own letter.

As it could be understood from what is said above the teacher in the school has good awareness on integration of reading and writing. However, particularly as witnessed during the classroom observation most of the times teachers used lectures on each reading and writing lesson in contrast to their responses in the interview.

\subsubsection{Motivation in teaching Integrated Reading and Writing skills}

The researcher also asked the teachers whether they motivate their students in learning the reading and writing lessons by means of integration. In responding to this item all of the respondents suggested that they motivate their students to read the given reading texts from their textbook. Then, they show them how texts are written. 
On the other hand, to ensure whether student understood the given reading texts before coming to the writing lesson, they stated that first in any reading texts there are activities that are classified into stages. These reading activities are the pre-reading, while-reading and post-reading in each reading text. After students completed the question under each stage, they pass to the writing session to teach the both skills by means of integration.

Resp2 similarly remarked that he gives brief introductions for his students on the given reading and writing texts, and advises them to develop their reading and writing skills together even for academic purpose. Also most of the time he makes students read loudly, gives lectures on the reading texts and further to check students understanding on the main points from the given reading texts, he asks general questions from the reading texts orally.Resp3 also confirmed this idea by suggesting that henries his best to motivate students in the both skills integration. In addition to this, he stated that different lexical words are given in the text and tries to use individual activities, pair work activities since it is easy to get each student's progress in reading and writing skills integration. However, it is too difficult to identify student's progress in reading and writing a short period of time

\subsubsection{In-service Training on Teaching of Integrated Reading and Writing}

It is known that adequate training, whether in-service training or pre-service training, is an essential means to make language teachers aware of modern approaches to teach English as a foreign language in general, skills integration in particular. In turn, the teachers' understandings of integrated-skills teaching along with the skills they have as to how practically implement reading and writing skills integration teaching dictates their course of actions in integrated-skills teaching. In the interview, the respondents were asked whether or not they had taken adequate in-service training about integrated-skills teaching particularly on how to integrate reading and writing skills. Accordingly, Resp1 in his explanation said:

I participated on ELIC given on Hassan. However, the training did not focus on how to teach the whole language skills. It was only about how to make students effective speakers in English language. Therefore, the training focused on one skill that is speaking not skills integration of reading and writing skills.

Similarly, Resp3 also stated that he participated on ELIC around 2007. On his further explanation, he stated that in the training there was experience sharing on how to teach. According to his respond training was about how to teach the language in general but not specifically focused on skills integration. As result of this, he couldn't get enough knowledge on how to teach English language skills particularly teaching reading and writing skills integration.

Resp4 similarly suggested that after he started teaching English at that school, he had got several chances to participate on different in-service training. Resp4, for example, stated that he participated on CPD. And he took also introduction courses that were given for fresh teachers. He tells that he had attended several in-service trainings, but none of these focused on language skills integration. As could be understand from the responses given by the respondents, the teachers did not get appropriate in-service training regarding languages kills integration. This may be one reason that made they not properly integrate the reading and writing and skills in the process of teaching reading and writing skills.

\subsubsection{Constraints in Integrating Reading and Writing skills}

According to the responses from the interview conducted with English language teachers, students' background, students' lack of interests, the size of the textbook, limited class time, and shortage of classrooms and teaching materials in the schools are identified as that affect the implementation of skills integration especially writing with reading sill. Among the constraints listed above, the frequently mentioned was students' background. They all reported that those students who come to their school from country said do not have good background about the language. They said that almost all of their students wait for spoon feeding. They are very slow even to understand what their teacher says. In connection to this, Resp4, for example rears the seriousness of the problems as follows:

Some of students are active in learning English while others are passive. Those active students can easily integrate the reading and writing activities but those passive students do not even understand the concept of the given reading text. They do not also understand the instructions given in reading and writing activities.

From the above explanation, researcher and other can understand that the varieties in students' level of learning English language can affect the successful implementation of language skills integration especially reading and writing skills integration.

As we can further understand from the respondents, students' lack of interest to learn the language is the second serious problem which affected not to implement reading and writing skills integration.Resp4 suggested that students lack interests to learn English language particularly writing and reading skill integration. In his further explanation, the respondents suggested that most of the time students are not ready to learn reading and writing skills in the classroom. There is less motivation to practice the reading and writing activities in the classroom and outside. Even they do not want to bring English textbook when they come to the class. Resp1 strongly explained that most of the students have belief that reading and writing skills integration are not necessary like other language skills since it is not presented on the national level examination. 
According to all of the respondents, student's textbook is one factor, which affects language skills integration particularly reading and writing skills. With regard to this, Resp3 suggested that the Grade Eleven English textbook has great problems on its contents, volume and activities. Some of the contents are repeated even in a single unit. The volume of the text is too vast. In his further explanation, the respondent suggested that it is difficult to cover the whole contents of the writing text when he integrates all contents of reading and writing lessons in each unit. Resp4 similarly stated that due to the size of the textbook, he prefers to escape some of the reading and writing contents that are written in the textbook.

The fourth factor mentioned by Resp4 is limited class tie to integrate reading and writing skills. He said that the time which is allotted for one teacher per period is 42 minutes. In his detailed explanation, these minutes are not enough to cover the day's lesson particularly when he teaches the reading and writing skill in integrated way.

The last factors mentioned by two respondents are shortage of classrooms and teaching materials to impalement skills integration particularly writing and reading. Resp4 remarked that there is no extra classroom to give tutorial for students in order to make them have further understandings in integrating reading and writing skills. On the other hand, there are no supplementary reading materials in the school.

As can be seen from the interview responses above, the problems that hinder the implementation of skills integration especially reading and writing skill are multifaceted. These are students' background, students' lack of interest, the size of textbook, limited class time, and shortage of classrooms and teaching materials in the schools.

\section{CONCULUTION AND RECOMMANDATION}

\subsection{Conclusions}

The main objective of this study was to investigate integration of writing and reading skills in Grade11English textbook. To achieve this objective, the researcher employed classroom observation, unstructured interviews and evaluation of document. Based on the result from classroom observations, interviews and tasks evaluation and the following conclusions have been drawn.

- $\quad$ According to the results obtained from the classroom observations concerning Grade Eleven English language teachers' practices in integrating writing and reading skills to some extent through the basic procedures of the language skills integration approach are not followed.

- Accordingly, on the basic of the results from the analysis of the observation data, most of the classroom writing and reading activities and exercises were conducted based on the textbook instructions and directions. The teachers rarely modified and adapted the writing exercises and activities according to students' language competence and learning interest.

- $\quad$ Concerning the major constraints which impeded the successful implementation of writing and reading skills integration. In classes, the major ones which frequently observed were passive involvement of students and shortage of textbook in the classroom. As a result, most of the students not direct their attention/ effort towards integrating the writing and reading skills.

- In the basis of the results obtained from the unstructured interview conducted with Grade Eleven English language teachers, all teachers has an awareness how to integrate writing and reading skills.

- The vast majority of the responses from the interview and Grade eleven textbook evaluations results indicate that most of writing and reading tasks are designed in line with integrating both skills.

\subsection{Recommendation}

Based on the conclusion derived above, the following recommendations are forwarded:

- $\quad$ Theoretically, teacher knows how to integrate writing and reading activities but practically less in skill integration particularly in writing and reading tasks. For this, it would be helpful if teacher training institutions (colleges or universities) aware of the gap between the teachers' theoretical knowledge of integrated-skills teaching and their practical skills of teaching language skills integration. Thus, the concerned bodies should facilitate situations and offers trainings to English language teachers on both the theoretical and practical aspects of integrated-skills teaching especially writing and reading skill integrations.

- $\quad$ Although most of the writing and reading tasks designed in Grade Eleven English textbook are found convenient to integrate writing and reading skills, textbook developers need to provide teachers with sufficient advice and guideline on how to integrate writing skills and reading skills. Various techniques to integrate reading and writing skills should be again recommended in the newly designed Grade Eleven English textbook. Finally, the study was made in investigating integration of writing and reading skills on sampled unit of Grade 11 textbook. Though, it is good if further research is conducted on the whole units of the grade 11 textbook specifically area of writing and reading skills integration. 


\section{REFERENCE}

Asmelash Haile (2003). The Impact of Microfinance in Ethiopia: The case of DECSI in Ganta- Afeshum Woreda of Eastern Tigray. Master Thesis, Addis Ababa University: Addis Ababa, Ethiopia. AlemayehuNagash (2008). A study of the practice of integrating language skills in the teaching of English.Unpublished MAThesis. Addis Ababa: Addis Ababa university.

Badger, R and white, G (2000). A process genre Approach to Teaching writing, ELT-Journal,vol.5, no.2.

Brown, Douglas, (1994). Teaching by principles: An interactive approach to language pedagogy. USA, prentices Hall.

Chen,Y. (2007). Students' changing views and the integrated-skills approach in Taiwan's EFL college classes. Asian EFL.Journal, v-8, No.1, P.27-40.

Krashen.S. (1993).The power of reading.Engleood, CO: Libraries Unlimited.

Harmer, J. (1991). The practice of English language teaching New York: Longman Ltd.

Seticker,L. and Tomlin, R.S. (1986). An Empirical look at the integration and separation of skills in ELT.Journal, vol. 40/3.

Richards, J.C. and T.S.Rogers.(1997). Approaches and methods in language teaching ( $2^{\text {nd }}$ edition). Cambridge: Cambridge University press.

Grabe, W., and Stoller, L.F. (2001). Reading for academic proposes: Guidelines for the ESL/EFL teacher. Boston: Heinle.

Widdowson, H.G. (1978). Teaching language as communication. Oxford: Oxford University press.

Oxford,R. (2001). Integrated Skills in the ESL/EFL classroom. University of Maryland: ERIC DIGESTS, EDO01-05.

Rahman,H. (2004). An evaluation of the teaching of reading skills of English in Bangladesh.University of rajshahi, rajshahi.

Raimes, A. (1991). Out of the woods: Emerging traditions in the teaching of writing TESOL.Quarterly, 25,407430.

Raphael, T.E. and et.al. (1986). The impact of the text structure instruction and social context on students comprehension and production of expository text. Michigan State University, Institute of research on teaching. 